\title{
Review of the Impact of Apple Fruit Ripening, Texture and Chemical Contents on Genetically Determined Susceptibility to Storage Rots
}

\author{
Hilde Nybom ${ }^{1, * \mathbb{C}}$, Masoud Ahmadi-Afzadi ${ }^{2}{ }^{\mathbb{D}}$, Kimmo Rumpunen $^{1}{ }^{\mathbb{C}}$ and Ibrahim Tahir ${ }^{3}$ \\ 1 Department of Plant Breeding-Balsgård, Swedish University of Agricultural Sciences, Fjälkestadsvägen 459, \\ 29194 Kristianstad, Sweden; kimmo.rumpunen@slu.se \\ 2 Department of Biotechnology, Institute of Science, High Technology and Environmental Sciences, \\ Graduate University of Advanced Technology, Kerman 7631818356, Iran; m.ahmadiafzadi@kgut.ac.ir \\ 3 Department of Plant Breeding, Swedish University of Agricultural Sciences, Box 101, 23053 Alnarp, Sweden; \\ ibrahim.tahir@slu.se \\ * Correspondence: hilde.nybom@slu.se
}

Received: 27 April 2020; Accepted: 29 June 2020; Published: 2 July 2020

\begin{abstract}
Fungal storage rots like blue mould, grey mould, bull's eye rot, bitter rot and brown rot destroy large amounts of the harvested apple crop around the world. Application of fungicides is nowadays severely restricted in many countries and production systems, and these problems are therefore likely to increase. Considerable variation among apple cultivars in resistance/susceptibility has been reported, suggesting that efficient defence mechanisms can be selected for and used in plant breeding. These are, however, likely to vary between pathogens, since some fungi are mainly wound-mediated while others attack through lenticels or by infecting blossoms. Since mature fruits are considerably more susceptible than immature fruits, mechanisms involving fruit-ripening processes are likely to play an important role. Significant associations have been detected between the susceptibility to rots in harvested fruit and various fruit maturation-related traits like ripening time, fruit firmness at harvest and rate of fruit softening during storage, as well as fruit biochemical contents like acidity, sugars and polyphenols. Some sources of resistance to blue mould have been described, but more research is needed on the development of spore inoculation methods that produce reproducible data and can be used for large screenings, especially for lenticel-infecting fungi.
\end{abstract}

Keywords: Botrytis cinerea; Colletotrichum; disease resistance; Malus $\times$ domestica; Monilinia; Neofabraea; Penicillium expansum; plant breeding

\section{Introduction}

Although apple Malus $\times$ domestica is one of the most important and well-studied fruit crops in the world, growers still face a number of unresolved problems with production, storage and marketing. A major proportion of the commercially grown fruit is intended for marketing after a period of at least four months in cold storage. However, fungal decay during storage leads to considerable losses of fruit. The situation is especially serious in low-input production systems (like organic orchards and agroforestry systems), where the fruit cannot be adequately protected by fungicides and losses can amount to 20 times as high as those in conventional orchards [1-3]. Grower revenues are often reduced since the fruit must be marketed after a shortened storage period.

The number of approved fungicides has decreased in conventional production systems, and postharvest applications are completely banned in an increasing number of countries [4], while treatment with the protective gas 1-MCP (1-methylcyclopropene) is avoided, e.g., in Scandinavia, for marketing reasons, thus emphasizing the need for apple cultivars with a higher resistance. 
As a consequence, we now see an increasing number of reports on the relative levels of resistance/susceptibility to various storage rots. Variation among cultivars in this respect may be associated with phenotypic and physiological traits like fruit-ripening behaviour, including changes in internal ethylene content (IEC), fruit texture, fruit epidermis structure and chemical contents like sugar and various antifungal components such as chlorogenic acid and quercetin [4-15].

In this review, methods for quantifying damage caused by various storage rots are described, and information is provided about the impact of some fruit-ripening-related traits on susceptibility to storage rots. Hopefully, this will be valuable for plant breeders aiming to produce cultivars with an improved ability to withstand attacks of storage rots.

\section{Fungi That Cause Storage Rot}

A number of ascomycete fungi, often known as storage rots, regularly attack apples both in the orchard and during cold storage (Table 1). Symptoms are first visible as lesions on the fruit epidermis and can proceed to rotting of the entire fruit. Some of the most important storage rots in apple belong to two biotrophic or hemibiotrophic genera and are also known as latent or quiescent infection pathogens, namely Neofabraea (e.g., N. alba (syn. N. vagabunda), N. kienholzii, N. malicorticis and N. perennans) and Colletotrichum (the most well-known being C. acutatum and C. gloeosporioides, both of which have been split into several taxa), while other important species include the mainly necrotrophic ('wound pathogens') Penicillium expansum, Botrytis cinerea, Monilinia fructigena and M. laxa [16-19] (Table 2). In addition, numerous fungi that can infect apple blossoms and cause large necrotic areas on the fruit are known as blossom-end rots or calyx-end rots [20]. Relative importance of these and other fungi, e.g., Alternaria spp., Botryosphaeria obtusa, Cadophora luteo-olivacea, Fusarium spp., Mucor pyriformis, Neonectria ditissima and Phacidiopycnis washingtonensis, varies widely between geographic areas as well as from year to year.

Table 1. Fungi commonly reported to cause storage rots in apple fruits.

\begin{tabular}{|c|c|c|c|}
\hline Taxon & Synonyms & Popular Name & References \\
\hline $\begin{array}{l}\text { Alternaria spp., e.g., A. alternata (Fr.) Keissl. and A. tenuissisima } \\
\text { (Kunze) Wiltshire }\end{array}$ & & Alternaria rot, calyx-end rot & {$[3,16,20,21]$} \\
\hline $\begin{array}{l}\text { Botryosphaeria spp., e.g., B. dothidea (Moug. ex Fr.) Ces. \& De } \\
\text { Not. and B. obtusa (Schwein.) Shoemaker }\end{array}$ & Diplodia seriata De Not., Sphaeropsis malorum & $\begin{array}{l}\text { Black rot (B. obtusa), white rot } \\
\text { (B. dothidea) }\end{array}$ & {$[20-22]$} \\
\hline Botrytis cinerea Pers. & & Grey mould, dry-eye rot & {$[8,16,21,23-26]$} \\
\hline $\begin{array}{l}\text { Cadophora spp., e.g., C. luteo-olivacea (J.F.H. Beyma) T.C. Harr. } \\
\& \text { McNew and C. malorum (Kidd \& Beaumont) W. Gams }\end{array}$ & $\begin{array}{l}\text { Phialophora luteo-olivacea J.F.H. Beyma and P. malorum } \\
\text { (Kidd \& Beaumont) McColloch, respectively }\end{array}$ & Side rot & {$[16,20]$} \\
\hline $\begin{array}{l}\text { Colletotrichum acutatum J.H. Simmonds incl. e.g., C. fioriniae } \\
\text { Marcelino \& Gouli ex R.G. Shivas \& Y.P. Tan }\end{array}$ & Glomerella acutata Guerber \& J.C. Correll & $\begin{array}{l}\text { Bitter rot (Glomerella leaf spot } \\
\text { on leaves) }\end{array}$ & {$[9,27-31]$} \\
\hline $\begin{array}{l}\text { Fusarium spp., e.g., F. avenaceum (Fr.) Sac., F. lateritium Nees ex. } \\
\text { Fr. and F. proliferatum }\end{array}$ & & Fusarium rot, wet core rot & {$[3,16,20,21]$} \\
\hline Monilinia fructigena (Aderh. \& Ruehl.) Honey ex Whetzel & Monilia fructigena (Pers.) Pers. & Brown rot & {$[16,19,21,38]$} \\
\hline Monilinia laxa (Aderh. \& Ruhland) Honey & Monilia cinerea Bonord. & Brown rot & [21] \\
\hline Neofabraea brasiliensis Sanhueza \& Bogo & & Bull's eye rot, lenticel rot & [39] \\
\hline $\begin{array}{l}\text { Neofabraea kienholzii (Seifert, Spotts \& Lévesque) Spotts, } \\
\text { Lévesque \& Seifert }\end{array}$ & Cryptosporiopsis kienholzii Seifert, Spotts \& Lévesque & Bull's eye rot, lenticel rot & {$[17,46]$} \\
\hline Neofabraea malicorticis (Cordley) H.S. Jacks. & $\begin{array}{l}\text { Gloeosporium malicorticis Cordley, Pezicula malicorticis } \\
\text { (Cordley) Nannf., Cryptosporiopsis malicorticis } \\
\text { (Cordley) Nannf. }\end{array}$ & Bull's eye rot, lenticel rot & {$[16,25,43-45]$} \\
\hline Neofabraea perennans Kienholz & $\begin{array}{l}\text { Gloeosporium perennans Zeller \& Childs, } \\
\text { Pezicula perennans (Kienholz) Dugan, R.G. Roberts \& } \\
\text { G.G. Grove }\end{array}$ & Bull's eye rot, lenticel rot & [44-49] \\
\hline Neonectria ditissima (Tul. \& C. Tul.) Samuels \& Rossman & Nectria ditissima Tul. \& C. Tul., Nectria galligena Bres. & $\begin{array}{l}\text { Nectria rot (apple canker or } \\
\text { European canker on trees) }\end{array}$ & {$[20,50]$} \\
\hline Penicillium expansum Link & & Blue mould & {$[3,5,6,12,15,21,25,31-33,38,51-66]$} \\
\hline $\begin{array}{l}\text { Phacidiopycnis spp., e.g., P. malorum Potebnia and } \\
\text { P. washingtonensis Xiao \& J.D. Rogers }\end{array}$ & Potebniamyces pyri (Berk. \& Broome) Dennis & Phacidiopycnis rot & [20] \\
\hline
\end{tabular}


Table 2. Infection mode and period of infection for some storage rots in apple fruits.

\begin{tabular}{lll}
\hline Taxon & Mode of Infection & Period of Infection \\
\hline Alternaria spp. & Mainly through open calyces & Developing fruit in the orchard \\
Botryosphaeria spp. & Mainly through lenticels or micro-cracks & Developing fruit in the orchard \\
Botrytis cinerea & Mainly through wounds caused by animals or humans & Mainly during harvest and handling operations \\
Cadophora spp. & Mainly through lenticels or micro-cracks & Developing fruit in the orchard \\
Colletotrichum spp. & Mainly through lenticels or micro-cracks & Developing fruit in the orchard \\
Fusarium spp. & Mainly through wounds or open calyces & Developing fruit in the orchard \\
Monilinia spp. & Mainly through wounds caused by animals or humans & Developing fruit and during harvest and handling operations \\
Mucor pyriformis & Through micro-cracks or wounds, often at stem or calyx end of fruit & Developing fruit (last month) or during harvest and handling operations \\
Neofabraea spp. & Mainly through lenticels or micro-cracks & Developing fruit in the orchard \\
Neonectria ditissima & Mainly through wounds or at calyx end of fruit & During and just after flowering (eye rot) and developing fruit (storage rot) \\
Penicillium expansum & Mainly through wounds caused by animals or humans & Mainly during harvest and handling operations \\
Phacidiopycnis spp. & Mainly at stem end or at calyx end, sometimes wound-mediated & Developing fruit in the orchard \\
\hline
\end{tabular}


The very common disease bull's eye rot, sometimes also known as lenticel rot, is caused by Neofabraea spp. These fungi infest the fruit during the growth phase in the orchards, from petal fall to harvest, with susceptibility increasing gradually during the ripening process [25]. The spores remain dormant in the lenticels and start to grow only when the fruit has reached a certain stage of maturity, probably due to physiological changes associated with a decline in fruit antifungal compounds or defence responses [42]. The germinating conidia form hyphae that penetrate the epidermis of the fruit, preferentially through open lenticels but also through the stem bowl and calyx-end regions, or through microcracks on the surface [22]. Bitter rot, caused by Colletotrichum spp. has a similar mode of infection [67]. Symptoms of the lenticel-infecting fungi usually do not appear until the fruit has been kept in cold storage for some weeks and thereafter at room temperature for some days. Moreover, storage-rot-producing species of Neofabraea can also cause perennial cankers (anthracnose) on apple trees, thus ensuring year-round survival of the pathogen in the orchard [46], while species of Colletotrichum are responsible for the widely dispersed Glomerella leaf spot disease (named after the sexual stage of $C$. gloeosporioides, namely Glomerella cingulata) $[35,36]$.

The most well-studied of all storage rots to date is P. expansum (blue mould), which causes serious damage to apple crops all around the world. This fungus also produces the mycotoxin patulin, which is very harmful to human health and occurs as a contaminant especially of apple juice and unfermented apple cider $[68,69]$. Infections by $P$. expansum, as well as by some other storage rots like B. cinerea (grey mould) and $M$. fructigena (brown rot), are mainly wound-mediated. The hyphae enter through wounds, e.g., caused by birds and insects or the inattentive handling of the fruit during harvest, storage and transportation, but infection can also take place through an open calyx of the flower [25]. Symptoms are sometimes visible already in the orchards, but develop mainly during storage.

\section{Quantification of Storage Rot Damage}

Genetic variation among cultivars (each cultivar usually corresponds to a single genotype in apple and other clonally propagated crops) is the basis for selection-mediated improvement, and the subsequent development of superior cultivars. Considerable variation among cultivars in their susceptibility to some of the most common storage rots has been reported from observations in orchards and storage rooms $[3,19,21,40,43,70]$. Still, levels of resistance cannot be properly quantified based only on natural infections, since the inocula may vary in both quantity and virulence. There are also problems with attributing visible damage to a particular fungal species since symptoms on the fruit may stem from several fungi. Taxonomically correct identification of the involved fungi can be difficult, and morphological evidence may have to be complemented with time-consuming molecular analyses $[16,21,44]$.

In order to obtain properly quantifiable data for a large set of genotypes, experimental inoculations with well-defined inocula have been carried out for several fungi (Table 3). For the wound-mediated storage rots like P. expansum, B. cinerea and $M$. fructigena, inoculation is usually achieved by wounding and inoculating a number of fruits with conidiospores of the fungus $[5,8,15,21,24,25,31,49,56,57]$. Wounding and inoculation can be carried out simultaneously, using a pipette with disposable plastic pipette tips to create one to three inoculation sites on each fruit, allowing large numbers of fruit to be processed in a limited amount of time. Disease severity is usually assessed as the diameter of each lesion, measured at a predefined point in time after a period of storage. A lesion expansion growth rate (LEGR) can be calculated by linear regression if repeated measurements are made over several days or weeks [28]. In addition to the most commonly used parameter, i.e., lesion diameter $=$ disease severity (S), the percentage of inoculations producing a lesion can be quantified as disease incidence (I). Infection severity is sometimes calculated as $(\mathrm{I} \times \mathrm{S}) / 100$. However, I and S were closely correlated in a study on wild accessions of M. sieversii that had been wound-inoculated with P. expansum [56]. 
Table 3. Inoculation methods for quantification of damage caused by storage rots.

\begin{tabular}{|c|c|c|}
\hline Method & Fungi & References \\
\hline \multicolumn{3}{|l|}{ On trees-spores } \\
\hline Cheesecloth strips: strips soaked in spore suspension applied to fruit in orchard 3-4 weeks prior to harvest & Colletotrichum acutatum & [27] \\
\hline Spraying: spore suspension sprayed onto fruit in orchard; most efficient towards end of growing season & Neofabraea spp. & [46] \\
\hline Spraying: spore suspension sprayed onto flowers and fruit on potted trees & Neonectria ditissima & [50] \\
\hline \multicolumn{3}{|l|}{ Detached fruit-spores } \\
\hline Agar plate: intact fruit placed on petri plate with agar and a droplet of spore suspension & C. acutatum & [67] \\
\hline Attached tubes: spore-suspension-containing microcentrifuge tubes attached to fruit with modelling clay & C. acutatum & [27] \\
\hline Dipping: intact fruit dipped in spore solution & C. gloeosporioides & [8] \\
\hline \multirow{2}{*}{ Spraying: spore suspension sprayed onto intact fruit } & C. fioriniae & [30] \\
\hline & Neofabraea alba & [43] \\
\hline Water agar: intact fruit placed on water agar with a droplet of spore suspension & N. alba & {$[28]$} \\
\hline \multirow{4}{*}{ Wound inoculation: spore solution deposited into $1-5$ holes made by a nail or a pipette tip in the fruit skin } & Penicillium expansum & {$[46,56]$} \\
\hline & Botrytis cinerea & [8] \\
\hline & Colletotrichum spp. & {$[27,30]$} \\
\hline & Neofabraea spp. & {$[25,49]$} \\
\hline \multicolumn{3}{|l|}{ Detached fruit—mycelium } \\
\hline Mycelial discs: attachment of five $7 \mathrm{~mm}$ large discs onto the fruit using adhesive tape & Botryosphaeria dothidea & [22] \\
\hline \multirow[t]{2}{*}{ Mycelial plugs: plugs inserted into fruit flesh, sometimes under the skin of the fruit } & Neofabraea spp. & {$[39,40,45]$} \\
\hline & B. cinerea & [26] \\
\hline
\end{tabular}


The wound-inoculation method has been applied also for fungi that usually enter through the lenticels, like Colletotrichum $[5,27,30,31]$ and Neofabraea $[25,48,49]$. Conidiospores for the inoculum can be more difficult to produce for some of these species compared to P. expansum, and inoculation success may be somewhat lower [5]. Additionally, contamination by faster growing fungi, like P. expansum, can become quite problematic.

Since wound-inoculation data cannot provide an estimate of the ease with which lenticel- and micro-crack-infecting fungi enter the fruit, inoculum is sometimes instead sprayed onto the fruits, either while still growing on the tree $[46,50]$ or after harvest $[30,43]$. Dipping the entire fruit into a spore solution has also been practiced [8]. Dipping and spraying often produce several infections on the same fruit, but symptom development is slower and less consistent compared to wound inoculations [30]. The resulting symptoms are usually quantified as number of lesions or as relative affected area, but the obtained high standard deviations may render this method unfit for comparisons of cultivar susceptibility [30]. In another study, spores of N. alba were placed on water agar, and fruits were placed on these spores in a Petri dish for at least 7 days to establish an infection [28]. Reliable infection of $66-100 \%$ of the fruits required 14 days of contact. A similar approach was used also for C. acutatum, with a wetness period of $72 \mathrm{~h}$ required for lesion development [67].

In a comparative study, Biggs and Miller [27] inoculated a set of 18 apple cultivars with C. acutatum using three methods: (1) dressing fruits in the field 3-4 weeks pre-harvest with cheesecloth strips soaked in a spore solution, (2) wound-inoculation of fruit harvested 2-3 weeks before their normal harvest date, and (3) attachment of a microcentrifuge tube with a spore suspension onto an unwounded surface of the very same fruits as used in the wound inoculations. The third method, which was quite labour-intensive, showed the highest reproducibility between the two years of experiments; both disease incidence and disease severity (lesion size) produced meaningful data.

All the methods described above are based on inoculation with conidiospores, but some studies have instead utilized mycelia. Mycelial discs ( $7 \mathrm{~mm}$ diameter) were cut with a cork borer from the edges of actively growing cultures of Botryosphaeria dothidea, and five discs were then taped onto a detached fruit [22]. Similarly, small pieces of mycelia from N. alba have been inserted as plugs into fruit flesh, or placed in pockets under the skin of the fruit $[40,45]$. In a slightly modified version, fruit pulp plugs $(5 \times 3 \mathrm{~mm})$ were extracted from detached fruit and replaced with equal-sized mycelial plugs of 21-day old Neofabraea cultures, covered by moist cotton and sealed with Parafilm [39]. Significant differences in lesion size were found among the inserted fungal isolates, but not between the two apple cultivars. Mycelial plugs have also been used for inoculation with Botrytis cinerea [26]. These methods are, however, considerably more time-demanding than the spore-based methods, and have not yet been used for screening large sets of cultivars/genotypes.

The inoculated fruit is often kept at room temperature while infections develop. Lesions usually appear within a few days, and the damage can be scored within a week after inoculation, although slow-growing fungi like Neofabraea may require incubation for 15 days [39] or a whole month before symptoms have developed sufficiently [28]. In one approach, some fruits were wound-inoculated with Colletotrichum either at harvest or after three months of cold storage [30]. The inoculated fruits were subsequently kept at room temperature until evaluation of symptoms for a period of 4 to approximate 20 days. The lesions derived from inoculation of previously cold-stored fruit developed faster and showed a higher cultivar effect, presumably because the fruits were more mature when infected.

In studies aiming to compare large sets of cultivars for their innate susceptibility to storage rots, commercial cold-storage conditions are often applied during disease development $[5,15,25]$. In studies of lenticel-infecting fungi like Neofabraea, cold storage is usually followed by 5-7 days at room temperature in order for symptoms to develop properly. In a broad screening, the number of weeks in cold storage may need to be adjusted for ripening period of the cultivars; early-ripening cultivars ('summer varieties') can usually be stored only for a few weeks before major decay due both to fungi and other factors sets in. By contrast, late-ripening cultivars ('fall and winter varieties') may 
have to be stored for 10 weeks or longer in order for lesions to develop properly. For comparison of cultivars stored for different lengths of time, a lesion decay index can be obtained by dividing the average lesion diameter by number of weeks in storage [15].

Great care must be taken not only in the inoculation and storage procedures, but also in the origination of the fruit to be tested. Ideally, the harvested trees should have been grown in the same orchard and have a similar age, since fruit on younger trees are more susceptible to infections such as N. malicorticis [71]. The fruits should also be harvested at the same maturity stage; fully mature fruit are more susceptible to various storage rots $[4,41,53,56,59,67,72-74]$. Since apple cultivars differ widely in ripening period, the inoculations have to be staggered in time so that all genotypes are inoculated at an optimal stage. Ideally, the inoculations should be repeated over several years, as fruit-ripening parameters are very sensitive to weather fluctuations. Fortunately, wound-based inoculations with P. expansum $[5,15]$ and with C. acutatum [27] show reasonably high reproducibility between years. Even higher reproducibility was, however, obtained with attached microcentrifuge tubes, whereas field inoculation with cheesecloth strips produced data that were not correlated with the laboratory methods [27].

In addition to producing reproducible data, an efficient inoculation method must also be able to differentiate properly among a large number of cultivars. Significant variability among cultivars has been reported after wound-inoculation of harvested fruit with P. expansum $[5,15,25,58,60]$. Some well-known commercial cultivars, e.g., 'Fuji', 'Gala', 'Gloster', 'Katja'/'Katy' and 'Mutsu', appear to be relatively resistant, as do some locally grown cultivars, e.g., the Chinese 'Fu Shuai', Latvian 'Olga' and Russian 'Pepin Schafranovij'. Interestingly, some genotypes of the apple progenitor species $M$. sieversii appear to be highly resistant $[31,52,56,57]$. Wound inoculation with the wound-mediated fungus $B$. cinerea has similarly produced significant differences among cultivars $[8,25]$. This method has also been successfully applied for lenticel-infecting fungi like N. malicorticis [25], N. sp. ('Gloeosporium fructigenum' [8]) and C. acutatum [5,27,31]. In a comparative study, wound inoculation with $C$. fioriniae was deemed to be more suitable for research purposes than spraying, since symptoms on sprayed fruit were difficult to quantify [30]. Unfortunately, it is presently not possible to identify cultivars with above-average resistance to fungi other than P. expansum, as screenings for those fungi have generally included a very restricted number of genotypes.

\section{Resistance Mechanisms and Quest for Resistance Genes}

For the biotrophic and lenticel-infecting fungi, the number of lenticels and thickness of the cuticular layer of the fruit are crucial factors, as shown in a study of 11 apple cultivars colonized by Botryosphaeria dothidea, which causes apple ring rot in Asia [22]. Similarly, an open calyx in the flower can provide an entry point for several storage rots (Table 2). For both biotrophic and necrotrophic fungi, infection ability is also dependent on the complex interaction between the fungi and their hosts in sophisticated recognition and signalling networks. A common response of a plant after fungal attack is the accumulation of reactive oxygen species (ROS) known as an oxidative burst. This can have a detrimental effect on the pathogen directly, damaging the plasma membrane and mitochondrial proteins, but can also activate various defence pathways in the attacked plant $[57,66]$. The plant then needs to remove excess ROS in order to protect itself, which is usually accomplished via an increase of ascorbate and glutathione. The fungal attack proceeds by a production of various compounds that can overcome the innate immune system of the host, including phytotoxic compounds, cell-wall-modifying enzymes and proteinaceous effectors. These changes have complex effects on several different substances in the fruit. Content of total phenols thus increased shortly after inoculation with P. expansum in one study, possibly due to activation of phenylalanine-ammonia lyase, and then decreased again [38]. Žebeljan et al. [66] observed a decline in fructose, malic acid, shikimic acid and total ascorbate content six hours post infection (hpi) with P. expansum. This was followed by a significant increase in malic acid at $24 \mathrm{hpi}$, and in total glutathione three days post infection (dpi). Finally, at $5 \mathrm{dpi}$, there was a significant increase in sucrose together with a decline in glucose and ascorbate. 
Similar studies have been carried out after inoculations with B. cinerea. The susceptible cultivar 'Braeburn' initially had a higher content of ascorbate in the peel and of other antioxidants in the fruit flesh after infection with this fungus, together with a more pronounced oxidative burst after two weeks, in comparison with the almost completely resistant 'Golden Delicious' [23]. By contrast, infection with $B$. cinerea produced an increase in chlorogenic acid in the relatively resistant cultivar 'Qinguan', but a decrease in the more susceptible 'Fuji' [24]. Several enzymes, including phenylalanine-ammonia lyase, also showed higher activity in 'Qinguan' compared to 'Fuji'. Obviously, associations between contents of various antioxidants and levels of enzyme activity on the one hand, and degree of resistance/susceptibility on the other hand, are not clear-cut.

Pectin degradation of cell walls is part of the fruit-ripening process in apples, and cell-wall degradation can be hastened through the secretion of lytic enzymes by the fungus, like cellulase and especially xylanase [43]. Unripe apples have relatively low $\mathrm{pH}$ (reaching below $\mathrm{pH}=4$ in some cultivars), but pathogens can decrease or increase this value. Penicillium expansum lowers the $\mathrm{pH}$ of its host via production of various organic acids (especially gluconic acid), thus providing an optimal environment for the cell-wall-degrading enzymes [12,54]. Interestingly, mutant strains of P. expansum that lack the global carbon catabolite regulator (CreA) cannot produce patulin and are also avirulent, due to a decreased ability to produce proteolytic enzymes and to acidify the in planta environment [62].

Among the common defence pathways of the plant, a major role has been indicated for jasmonic acid- and ethylene-mediated defence responses, as well as the phenylpropanoid metabolism [24]. Application of the ethylene-mediating plant hormone methyl jasmonate (MeJA) onto apples enhances expression of several ethylene-related genes like MdACS1 (1-aminocyclopropane-1-carboxylate synthase) and MdACO1 (1-aminocyclopropane-1-carboxylate oxidase) [75,76]. Both of these genes are associated with inter-cultivar variation in fruit firmness at harvest and after storage $[77,78]$, which appears to be an important component in the resistance against storage rots. Application of n-propyl dihydrojasmonate similarly induced ethylene production and an increased activity of several ethylene-related genes, and also resulted in smaller lesions on apples inoculated with B. cinerea [26].

The importance of these pathways has been corroborated by gene expression studies. A whole-genome apple microarray with 60 thousand transcripts was used to identify genes in P. expansum-infected fruits of four apple cultivars, two less susceptible and two very susceptible [51]. Transcriptomic analyses of fruit sampled 1 week and 6 weeks after inoculation produced large differences between the very susceptible and the more tolerant cultivars. Potential candidates were identified among defence- and oxidative-stress-related genes, cell-wall modification and lignification genes, and genes related to localization and transport. The fundamental role of the cell wall as an important barrier was demonstrated by induction of a cell-wall-related gene. Similarly, three genes involved in the 'downstream' flavonoid biosynthesis pathway were implicated as being important for resistance. In addition, exogenous application of MeJA reduced the symptoms resulting from inoculating fruit with P. expansum. A comparison between a more resistant genotype of $M$. sieversii and the susceptible $M . \times$ domestica cultivar 'Royal Gala' was carried out on fruit sampled $0-48 \mathrm{~h}$ after inoculation with P. expansum [52]. As expected, gene expression analysis suggested a higher basal level of resistance in $M$. sieversii compared to that in 'Royal Gala', as well as a more rapid and intense defence response to wounding and to wounding plus inoculation. Again, ethylene-related genes and genes involved in the 'jasmonate' and 'MYB-domain transcription factor family' groups were overexpressed in the resistant genotype.

In a study based on inoculating apples with both P. expansum and the non-host pathogen P. digitatum, infection by P. expansum reduced the ethylene climacteric burst in the fruits together with induction of the $M d A C O 3$ gene, together with downregulation of ACO (1-aminocyclopropane-1-carboxylic acid oxidase) enzyme activity and overexpression of ACS (1-aminocyclopropane-1-carboxylic acid synthase) activity [64]. The authors hypothesized that $P$. expansum 'manipulates' the endogenous ethylene biosynthesis in apples, leading to the circumvention or suppression of effective defences against the fungus. In another study, fruits infected by P. expansum showed higher peaks in both ethylene content 
and respiration compared to uninfected fruits, together with reduced membrane integrity and fruit firmness [54].

Wang et al. [65] focused on just the first six hours after infecting apples with P. expansum. The main differentially expressed genes identified in P. expansum were related to cell-wall-degradation enzymes, anti-oxidative stress, $\mathrm{pH}$ regulation and effectors. The host responded by activating pathogen-associated molecular pattern (PAMP)-triggered immunity (PTI) one hour after infection, and effector-triggered immunity three hours after infection. In another gene expression study of P. expansum, genes coding for pectin degradation were again shown to be upregulated during infection of apple [79]. Barad et al. [32] showed that gene expression patterns of P. expansum are, however, extremely versatile; some genes expressed during infection of apple were $\mathrm{pH}$ neutral, while others were similar to those obtained when growing the fungus in vitro at $\mathrm{pH} 4$ or at $\mathrm{pH} 7$, respectively. In the same study, infected apple tissue responded by upregulating genes involving jasmonic acid, mevalonate and flavonoid biosynthesis pathways, but the response was stronger towards P. expansum than towards C. gloeosporioides.

Virulence mechanisms differ widely between different fungi, and the involved compounds and pathways vary accordingly. Some fungi like C. gloeosporioides produce large amounts of ammonia during penetration and necrotrophic colonization of apples, thus raising the $\mathrm{pH}$ to over 8 [14]. The fungus-mediated $\mathrm{pH}$ changes are affected by genetically determined inter-cultivar variation in sugar content during ripening and at the final stage of maturity, and therefore also have an impact on the level of susceptibility [33]. For the lenticel-infecting fungi, the mechanisms by which the fungus can enter and then infect the fruits are of course critical. A gene expression study carried out in C. fructicola (belonging to the C. gloeosporium group) focused on the transcriptome in four types of fungal tissue, namely conidia, appressoria and infectious hyphae, sampled on inoculated apple leaves and in vitro using a cellophane membrane [34]. In the conidia, upregulated genes indicated a shunt towards triacylglycerol biosynthesis and thus an increased production of lipid droplets which constitute an important energy reserve. For penetration of the host tissue, melanization of the appressoria is a critical stage, as also reflected in the upregulation of genes involved in melanin biosynthesis. Growth inside fruits was not investigated, but growth of hyphae in apple leaves showed an upregulation of genes responding to phosphate starvation, thereby indicating a phosphate-depleted in planta environment.

Detection of genes with an impact on the resistance against storage rots has been attempted via different avenues. Traditionally, major genes and QTLs (quantitative trait loci) are identified based on a molecular-marker-mapped population with offspring that segregate for the trait of interest. A dense genetic map (3441 SNP markers) based on restriction-site-associated DNA sequencing (RADseq), enabled the location of QTLs controlling fruit firmness, sugar content and acidity in apples to be identified [80], i.e., traits that may have relevance for storage-rot resistance. Recently, inoculation of fruit harvested from a mapping population of 'Royal Gala' $\times$ Malus sieversii PI613981 resulted in the identification of two QTLs for resistance against P. expansum on LG3 and LG10, respectively [59]. The stronger of these, mapped from 67.3 to $74 \mathrm{cM}$ on LG3 (qM-Pe3.1), explained $27.5 \%$ of the variation and appeared to derive from the $M$. sieversii parent. The second QTL, mapped to LG10, was presumably inherited from 'Royal Gala'. Genes and QTLs for firmness and ripening have previously been found in the same region on LG10, and may be involved in this lower-level resistance.

Genome-wide association study (GWAS) is a more recent approach, which exploits the linkage disequilibrium present among individuals from natural populations or germplasm collections. These are usually more diverse than segregating progenies, and can be used to map QTLs with a higher resolution. In addition, the recent development of high-density SNP arrays with uniform coverage of the whole genome, makes it possible to obtain data for very large numbers of mostly anonymous markers. A 20K Infinium SNP Array (Illumina) was thus used in a GWAS to map QTLs for apple fruit volatiles, and to reveal their interplay with fruit texture by also scoring two functional markers, $M d P G 1$ (polygalacturonase 1), involved in the depolymerization of pectin, and MdACO1, catalysing the last step in the production of ethylene [81]. Interestingly, cultivars with a high aromatic volatile production usually had soft flesh, while cultivars with firm and crispy fruit had notably less aroma. 
Strong interplay between fruit-ripening-related traits of firmness and aroma are indicated; ethylene is known to affect the production of fruit volatiles, and a QTL for volatiles was also found in the same location as MdPG1 on LG10.

The 20K Infinium SNP Array was also used in another fruit-texture analysis [82] with two approaches: GWAS on a collection of apple cultivars, and PBA (pedigree-based analysis) using six full-sib families. One QTL on LG10 appeared to determine fruit firmness while two QTLs on LG2 and LG14 were associated with crispness. GWAS have also been carried out using the Axiom ${ }^{\circledR}$ Apple $480 \mathrm{~K}$ array developed within the Fruitbreedomics project [83]. Eight QTLs, two for flowering period and six for fruit-ripening period, could be mapped with high resolution using a total of 1168 apple genotypes [84]. Geographic origins and genetic relatedness among cultivars accounted for a large part of the phenotypic variation, suggesting that selection has been undertaken in response to the different growing environments.

In an unpublished GWA study (Ahmadi-Afzadi, Muranty, Nybom and Durel) with lesion size data collected for 180 P. expansum-inoculated, mostly N. European apple cultivars, a not fully significant association with lesion decay was found on the bottom part of LG3 with the above-mentioned Axiom ${ }^{\circledR}$ Apple $480 \mathrm{~K}$ array (Figure 1). A considerably larger sample size is generally needed for the detection of significant SNP-based associations in unrelated material [85]. Whether this putative QTL is close to the QTL for resistance against P. expansum in M. sieversii as described by Norelli et al. [59] has not been established yet. Nevertheless, the implications are highly interesting, since co-location of these two QTLs would indicate that there is considerable variation for P. expansum resistance not just in the wild species of $M$. sieversii, but also in $M . \times$ domestica.

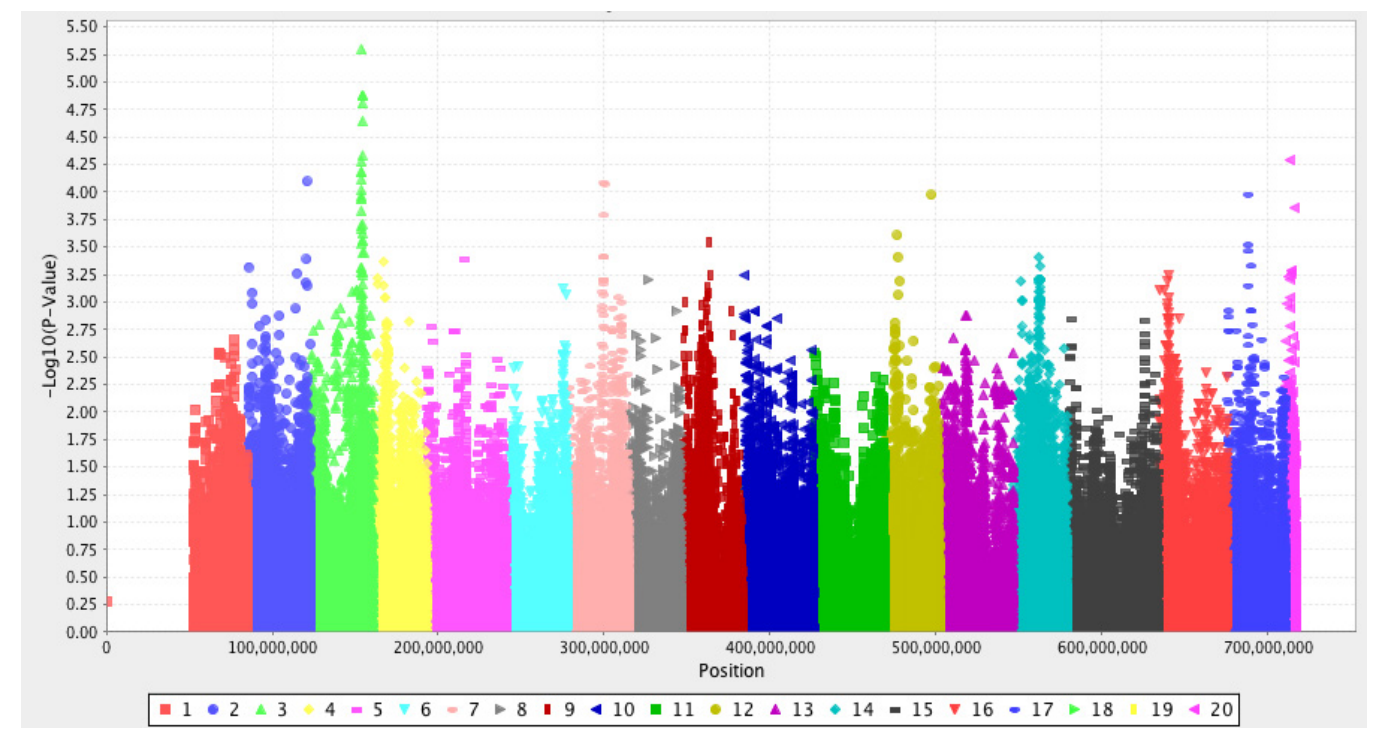

Figure 1. A Manhattan plot displays associations between data for lesion decay of 180 Penicillium expansum-inoculated apple cultivars and SNPs (single nucleotide polymorphism) in the Axiom ${ }^{\circledR}$ Apple $480 \mathrm{~K}$ array for DNA samples of the same cultivars (Ahmadi-Afzadi, Muranty, Nybom, and Durel, unpublished). Genomic coordinates are shown along the $x$-axis with different colours according to which of the 17 apple-genome linkage groups each SNP is situated on, while the negative logarithm of the association $p$-value is displayed on the $y$-axis. A possible association is indicated on the bottom part of LG3 (bright green), but it was not statistically significant since the significance threshold (6.5) was higher than in most other GWAS due to the overall very large number of SNPs in the study.

Nowadays, genes can also be located using the increasingly affordable methods for whole-genome re-sequencing. Together with bulked segregant analysis, this type of data was used to locate genes for resistance against Glomerella leaf spot caused by $C$. fructicola $[35,36]$. Genome-wide comparison of SNP profiles between the resistant and the susceptible bulks, constructed from F1 individuals 
derived from a cross between 'Golden Delicious' and 'Fuji', enabled the fine-mapping of an Rgls locus on LG15. Whether markers for resistance against Glomerella leaf spot will prove to be useful for predicting resistance against storage rot on apple fruits caused by the same species remains to be seen. Previous studies have shown that at least some isolates of $C$. fructicola show clear organ specialization, with differences in their impact on the enzymatic oxidant defence system of the host [37].

\section{Impact of Fruit Ripening Period, Fruit Texture and Chemical Contents}

In this review, 'ripening period' refers to the date at which a particular cultivar is ready for (commercial) harvest. When many cultivars are investigated in the same study, ripening period is usually quantified as the number of days between harvest of the earliest-ripening cultivar and harvest of the cultivar in question. Comparative scoring data for cultivars grown at different sites can be obtained by defining ripening period relative to well-known major cultivars like 'Gala' or 'Golden Delicious' grown at all sites, and a correction for site and year if needed [84]. 'Fruit maturity' instead refers to the stage (e.g., unripe, medium ripe, overripe) that a particular fruit may have reached $[86,87]$. Early-ripening cultivars (summer apples) generally have high climacteric respiration and ethylene production rates and mature quickly, whereas late-ripening cultivars (autumn apples) have lower respiration and ethylene production rates and mature more slowly [4].

Determination of fruit 'texture' is complicated since many different variables are involved, with consumer-perceived chewiness, crunchiness, juiciness, crispness and firmness being especially important. Firmness is the most commonly investigated parameter, since it can be assessed with a simple handheld penetrometer. An automated texture analyser, measuring several texture parameters simultaneously, has been used in some recent studies. When analysing 86 apple cultivars with this device, a set of mechanically based variables showed high correspondence to 'firmness' while an acoustics-based set corresponded to 'crispness' as perceived by human senses [88]. Firmness is often measured both at harvest and after storage, since it decreases during the harvesting period, usually with a major reduction in conjunction with, or more commonly, just after the climacteric rise in IEC [4]. Commercial fruit, especially if destined for long-term storage, is usually harvested when it is in a kind of steady state, i.e., before the rise in IEC. In addition to the initial firmness, amount of firmness retained after cold storage is crucial for the choice of apple cultivars in modern orchards. Loss in firmness (difference in firmness between measurements) is termed fruit softening and is sometimes divided by number of weeks in storage to yield 'softening rate', which enables comparisons to be made among cultivars stored for different periods of time [78]. Large-scale screenings of Swedish and Norwegian cultivar collections have revealed positive associations between ripening period with firmness at harvest (early-ripening cultivars are less firm at harvest compared to late-ripening cultivars) and negative associations between ripening time and softening rate (early-ripening cultivars lose firmness faster than late-ripening cultivars) $[15,78]$. By contrast, no correlation was found between commercial harvest date (i.e., ripening period) and fruit firmness when 23 Belgian cultivars were compared [8].

Amounts of various chemical compounds, both in the flesh and in the peel, are to a large extent affected by environmental factors like soil, pruning, fertilizer, irrigation and weather conditions $[4,89]$. To the extent that chemical contents also differ genetically among cultivars, genotypes with high contents of beneficial compounds could become very valuable in breeding for resistance. Quantification of chemical contents in a set of different apple genotypes is however quite complicated, and evaluations must be made at comparable stages of fruit maturation. Sugars (often estimated as soluble solids content, SSC) increase considerably in the fruit flesh due to starch hydrolysis during the ripening process, while acids (often estimated as titratable acidity, TA) decrease through respiratory metabolism [4]. The ripening behaviour of the studied cultivars may also interfere; fruit of early-ripening cultivars have been noted for relatively low levels of ascorbate at harvest and a more rapid reduction during the following 10-day period compared to fruit of late-ripening cultivars [8]. In addition, chemical contents in the fruit commonly change as a response to infection; different species of fungi acidify or alkalify their 
environment to facilitate infection and necrotrophic growth in the fruit [14]. Sugars, i.e., mainly sucrose in apples, have an important role in respiration and energy consumption which increases after infection. For the defence mechanisms, various phenolic substances may, however, be the most important.

\section{Possible Associations between Fruit Ripening and Resistance}

Wound inoculations were carried out in a set of 92 Swedish-grown apple cultivars in 2010 and in a set of 45 cultivars in 2012, with 45 fruits inoculated for each cultivar [5]. The fruits were all picked at a maturity stage corresponding to commercial harvest date, and had been stored for 6 (early-ripening cultivars) or 12 weeks (late-ripening). A significant negative correlation was found between lesion diameter and harvest date (i.e., ripening period) for both early-ripening and late-ripening cultivars in 2010 , but only for late-ripening cultivars in 2012. In a similar study of 45 cultivars grown in Sweden and 45 cultivars grown in Norway, investigated in 2012 and 2013, lesion diameter was again negatively correlated with ripening period [15]. As expected, lesion diameter was negatively correlated with firmness at harvest, and positively correlated with fruit softening in both of these studies $[5,15]$. A negative association was similarly found between fruit firmness and lesion diameter in a study of Iranian cultivars [58]. The relationship between firmness and lesion decay reported here is probably associated with the ability of cell walls to withstand attacks from pectolytic enzymes of P. expansum. Susceptibility to another wound-infecting species, $B$. cinerea, similarly decreased with later commercial harvest period (i.e., high values for ripening period) in a set of 23 Belgian-grown cultivars [8]. The basis of this relationship is not known, but late-ripening cultivars tend to have firmer fruit and higher levels of antioxidants and ascorbate, among other compounds, both of which may improve resistance against fungi.

Wound inoculations carried out with C. gloeosporioides in a set of 70 Swedish-grown cultivars demonstrated a negative association between lesion diameter and ripening period in early-ripening cultivars but not in late-ripening [5], and also not for C. acutatum [27] (fruits of 18 cultivars inoculated by attaching a tube with inoculum) or C. gloeosporioides [8] (Gloeosporium rot; fruits of 23 cultivars dipped in a spore solution). Presently, it is not possible to determine whether the inconsistency between studies is caused by differences in inoculum or inoculation method, for example, or the low number of sampled cultivars in some of the studies. Cultivars assessed from natural infection to be resistant to the lenticel-infecting Pezicula alba (Neofabraea alba) had, on average, firmer flesh than susceptible cultivars, but considerable overlap was noted [40]. A corresponding relationship was found also when wound-inoculating 9 apple cultivars with C. fioriniae [30], but not when non-wound-inoculating 18 cultivars with C. acutatum [27]. Possibly, the ability to withstand pectolytic enzymes is overshadowed by parameters involved in fungal entry for non-wound-inoculated fruit.

Data have been collected for both chemical contents and lesion diameter after wound inoculation with $P$. expansum in a number of different apple cultivars, and/or germplasm of the wild species M. sieversii. In some of these studies, chemical analyses were executed only on healthy fruit, while both healthy and infected fruit were analysed in other studies. Associations between chemical compounds and other storage rots like B. cinerea and Colletotrichum spp. have also been investigated [8,30].

Content of TA (or malic acid, which constitutes the major portion of acids in apple) appears to be lower in P. expansum-inoculated fruits compared to control fruit $[6,63,90]$. The reason for this has not been determined, but fungal acidification seems to be mediated mainly by gluconic acid $(12,32,55]$. To what extent-if any-variation in TA of healthy fruit affects susceptibility is not clear. Weak, but still significant, negative correlations between TA in the fruit flesh at harvest and susceptibility to P. expansum were reported in $83 \mathrm{M}$. sieversii accessions [56], and in 43 Iranian-grown cultivars [58], whereas no correlations were found in analyses of the peel and flesh of 24 Swedish-grown apple cultivars [6], or in another set with 10 Swedish-grown cultivars [60]. There have been only a few corresponding studies on other fungi, but Davey et al. [8] reported a negative correlation between TA and lesions caused by inoculation with B. cinerea, and Blažek et al. [40] found a similarly negative association between TA in apple juice samples and lesions caused by storage rots in general. Although these negative 
correlations could be an indicator of resistance, they may also stem from a somewhat uneven level of maturity in the sampled genotypes; less mature and therefore comparatively sour apples are usually more resistant to storage rots.

The relationship between SSC in healthy fruit and lesion diameter after inoculation with P. expansum is also unclear. Naeem-Abadi et al. [58] reported of a weak negative correlation between lesion diameter and SSC, while Tahir et al. [15] did not find any correlation in two sets of 45 cultivars each (grown in Norway and Sweden, respectively). Janisiewicz et al. [56] instead reported of a weak positive correlation, and concluded that a high sugar content might contribute to the susceptibility of fruit to decay. SSC content in juice of 10 apple cultivars was also positively correlated with lesion diameter [60]. Similarly, LEGR (lesion expansion growth rate) from wound-inoculation of nine apple cultivars with C. fioriniae was positively associated with SSC [30]. However, the association may be affected by biased sampling, since a somewhat over-mature fruit tends to be sweeter and also more susceptible to storage rots.

An important role of polyphenols in the defence against P. expansum was deduced from a study showing that three relatively resistant $M$. sieversii accessions had higher concentrations of procyanidins, dihydrochalcone, flavonols and hydroxycinnamic acids compared to 'Golden Delicious' and a susceptible accession of $M$. sieversii [61]. In a larger study, contents of total phenols (TPH) and of 10 individual phenolic compounds were quantified in peel and flesh fractions of both control and P. expansum-inoculated fruits of 24 apple cultivars grown in Sweden [6]. Contents in the peel were 4-32 times higher (depending on cultivar) compared to the flesh, and were usually lower in inoculated fruits compared to healthy fruits. Correlation analysis revealed a significant association between lesion diameter in inoculated fruits and TPH in the peel, as well as various flavonols (quercetin compounds) and procyanidin B2. Analyses carried out on healthy control fruits of the same cultivars yielded fewer but still significant associations with the flavonol content, suggesting that pre-formed polyphenolic compounds may inhibit or decrease the development of disease in fruits upon fungal attack. By contrast, no associations were found involving the dihydrochalcone phloridzin, and only one significant association involving hydroxycinnamic acids, namely in the flesh of control fruits. In another study with 10 Swedish-grown cultivars, TPH as well as seven individual polyphenolic compounds were, as expected, overall much higher in the fruit of five cider apple cultivars originating from a recent breeding program at Long Ashton, UK, compared to fruit of five table apple cultivars. However, contrary to expectations, inoculation with P. expansum produced larger lesions in all of the cider cultivars compared to the table cultivars. In addition, significant positive correlations were found between lesion diameter and content of procyanidin B2, epicatechin and trimer aglycone. Since all five cider apple cultivars were offspring of the relatively susceptible table apple 'James Grieve', they may perhaps have inherited a genetically determined susceptibility unrelated to chemical contents.

Apple cultivars with comparatively high contents of anthocyanin and ascorbic acid showed less damage caused by Neofabraea spp. compared to cultivars with lower contents [47]. Similarly, higher contents of phenolic compounds were noted in both skin and flesh of comparatively resistant cultivars grown in the Czech Republic, while lower contents were found in cultivars susceptible to various storage rots [40]. The more resistant cultivars also showed overall higher contents of epicatechin, catechin and chlorogenic acid in the skin.

Chromosomes 3, 10 and 16 have shown associations with ripening period in progeny-based linkage-mapping studies [91-95]. In addition, a QTL on LG9 controls the tight linkage between early ripening and red flesh/red leaves [96]. By contrast, Migicovsky et al. [97] did not find any associations with harvest period on LG10 and LG16 in a GWAS based on single-locus tests, but identified associations with two SNPs on LG3. In the largest study so far, almost 1200 apple cultivars from six European germplasm collections were screened with the Axiom ${ }^{\circledR}$ Apple $480 \mathrm{~K}$ array [32]. This work identified in six SNPs with strong associations to ripening period: four on the bottom part of LG3, one on the bottom part of LG10 and one on the top of LG16. A number of candidate genes were located within the confidence intervals of these genomic regions, suggesting that transcription factors such as MADS- 
and NAC-containing genes have a major role. Whether the QTL on LG3 found by Norelli et al. [59] for resistance in $M$. sieversii against $P$. expansum, and the possible QTL for resistance among $M$. $\times$ domestica cultivars (Ahmadi-Afzadi, Muranty, Nybom and Durel, unpublished) have any connections with the QTL for ripening time found on LG3 [84,97] is not yet known.

Variation in fruit-texture parameters is apparently also under the control of multiple genes, affecting fruits at harvest and/or after storage, including MdACS1 and MdACO1, which have been mapped to LG15 and LG10, respectively [77,98]. A direct effect of ethylene on fruit texture is the regulation of enzymatic breakdown of cell walls and middle lamellae in the fruit. The biallelic endopolygalacturonase gene MdPG1, which affects fruit softening during ripening and cold storage, has also been mapped to LG10, at a distance of $37 \mathrm{~cm}$ from MdACO1 [98-100]. As far as we know, there have been no reports to date of significant associations between the allelic composition in any of these fruit-texture genes and susceptibility to the different storage-rot diseases.

A number of loci that affect chemical contents have been located on the apple genome, including Ma1 on LG16 for acidity [101]. One important QTL controlling phenolic compounds is co-located with MdLAR1 (leucoanthocyanidin reductase 1) on LG16, which affects acidity, bitter pit and fruit cracking [7,22]. In a recent study, 82 Swedish-grown apple cultivars previously phenotyped for fruit firmness, fruit softening rate and lesion diameter after wound inoculation with P. expansum, were subsequently screened by Taqman ${ }^{\circledR}$ and high-resolution melting (HRM) assays for 15 qPCR-based molecular markers [102]. These markers target loci linked to fruit texture and chemical composition on LG10 and LG16, and derive from the IRSCOA v1.0 developed by the RosBREED SNP Consortium [98]. The results revealed significant phenotype-genotype associations between two SNPs in the MdLAR1 locus (ss475881696 and ss475882555) and lesion diameter. Interestingly, Chagné et al. [98] reported these two SNP markers to be associated with both fruit acidity and fruit firmness and crispness. In addition, a non-significant relationship $(p=0.08)$ was indicated between fruit softening rate in the 82 Swedish cultivars and two SNPs in the Ma1 locus (ss475876558 and Ma1-SNP1455).

In parallel with the above-mentioned HRM analysis with 15 qPCR-based markers [102], association analyses were also conducted for chemical data previously collected on 20 apple cultivars (Ahmadi-Afzadi, Nybom, Kirk, and Chagné, unpublished data). Content of procyanidins in the fruit flesh was significantly associated with two loci (ss475883942 and ss475881704) on LG16, as was content of chlorogenic acid with another two loci (Ma1-SNP1455 and ss475883359) on LG16. Contents of several flavonols (quercetins) were also associated with the locus FEM-cg-19 on LG10. However, further studies with larger sample sizes are needed.

\section{Conclusions and Perspectives}

For necrotrophic storage rots like blue mould caused by P. expansum, animal- or man-made wounds in the fruit are major entry points. Wound inoculation with fungal spores can therefore produce relevant assessments of cultivar resistance. Penicillium expansum has been hypothesized to counteract the defence mechanisms of the fruit by manipulating its endogenous ethylene biosynthesis. This fungus also lowers the $\mathrm{pH}$ of the host tissue and secretes lytic enzymes that promote the degradation of cell walls. Consequently, late-ripening apple cultivars, which are often characterized by a lower ethylene climacteric burst and higher fruit firmness, seem to fare better than early-ripening cultivars when attacked by blue mould. Associations between lesion decay and chemical contents of the fruit are, overall, less clear-cut, but indicate that baseline contents of especially phenolic substances, as well as changes in contents caused by infection, have an effect on level of resistance. Much less information is available for other necrotrophs, like Botrytis and Monilinia, but resistance against these fungi is most likely similarly related to fruit-ripening behaviour.

Biotrophic storage rots like Colletotrichum and Neofabraea enter mainly through open flower calyces and/or through lenticels and micro-cracks in the developing fruit. Wound inoculations therefore measure only one part of the heritable resistance in these fungi. Unfortunately, non-wound-inoculation methods are more time-consuming to apply, and the resulting damage is more difficult to quantify. 
Due to the resulting low number of in-depth studies of these fungi, the impact of ethylene-related processes on resistance against biotrophic storage rots cannot yet be ascertained. So far, however, associations with ripening period and fruit firmness appear to be less clear-cut for Colletotrichum and Neofabraea compared to the better-studied P. expansum.

For plant breeders, superior germplasm with well-characterized major-impact genes, preferably provided with easy-to-use DNA markers, is number one on the wish-list. Optimal development of storage-rot-resistant apple cultivars would require a geographically very diverse germplasm in order to cover the large variation in ripening-period-related traits. Superior inoculation methods must therefore be developed in order to produce large sets of phenotypic data to act as a basis for genetic analyses.

Author Contributions: Writing-original draft preparation, H.N.; writing-review and editing, M.A.-A., K.R. and I.T. All authors have read and agreed to the published version of the manuscript.

Funding: This research received no external funding.

Conflicts of Interest: The authors declare no conflict of interest.

\section{References}

1. DeEll, J.R.; Prange, R.K. Postharvest physiological disorders, diseases and mineral concentrations of organically and conventionally grown Mclntosh and Cortland apples. Can. J. Plant Sci. 1993, 73, $223-330$. [CrossRef]

2. Jönsson, Å.; Nybom, H.; Rumpunen, K. Fungal disease and fruit quality in an apple orchard converted from integrated production to organic production. J. Sustain. Agric. 2010, 34, 15-37. [CrossRef]

3. Novotný, D.; Lukáš, J.; Brožová, J.; Ružicková, P. Comparison of the occurrence of fungi causing postharvest diseases in apples grown in organic and integrated production systems in orchards in the Czech Republic. Czech Mycol. 2019, 71, 99-121. [CrossRef]

4. Tahir, I.; Nybom, H. Tailoring organic apples by cultivar selection, production system, and postharvest treatment to improve quality and storage life. HortScience 2013, 48, 92-101. [CrossRef]

5. Ahmadi-Afzadi, M.; Tahir, I.; Nybom, H. Impact of harvesting time and fruit firmness on the tolerance to fungal storage diseases in an apple germplasm collection. Postharvest Biol. Technol. 2013, 82, 51-58. [CrossRef]

6. Ahmadi-Afzadi, M.; Nybom, H.; Ekholm, A.; Tahir, I.; Rumpunen, K. Biochemical contents of apple peel and flesh affect level of partial resistance to blue mold. Postharvest Biol. Technol. 2015, 110, 173-182. [CrossRef]

7. Chagné, D.; Krieger, C.; Rassam, M.; Sullivan, M.; Fraser, J.; Andre, C.; Pindo, M.; Troggio, M.; Gardiner, S.E.; Henry, R.A.; et al. QTL and candidate gene mapping for polyphenolic composition in apple fruit. BMC Plant Biol. 2012, 12, 12. [CrossRef] [PubMed]

8. Davey, M.W.; Auwerkerken, A.; Keulemans, J. Relation of apple vitamin C and antioxidant contents to harvest date and postharvest pathogen infection. J. Sci. Food Agric. 2007, 87, 802-813. [CrossRef]

9. Grammen, A.; Wenneker, M.; Van Campenhout, J.; Pham, K.T.K.; Van Hemelrijck, W.; Bylemans, D.; Geeraerd, A.; Keulemans, W. Identification and pathogenicity assessment of Colletotrichum isolates causing bitter rot of apple fruit in Belgium. Eur. J. Plant Pathol. 2019, 153, 47-63. [CrossRef]

10. Johnston, J.W.; Gunaseelan, K.; Pidakala, P.; Wang, M.; Schaffer, R.J. Coordination of early and late ripening events in apples is regulated through differential sensitivities to ethylene. J. Exp. Bot. 2009, 60, 2689-2699. [CrossRef] [PubMed]

11. Lattanzio, V.; Venere, D.D.; Linsalata, V.; Bertolini, P.; Ippolito, A.; Salerno, M. Low temperature metabolism of apple phenolics and quiescence of Phlyctaena vagabunda. J. Agric. Food Chem. 2001, 49, 5817-5821. [CrossRef] [PubMed]

12. Prusky, D.; McEvoy, J.L.; Saftner, R.; Conway, W.S.; Jones, R. Relationship between host acidification and virulence of Penicillium spp. on apple and citrus fruit. Phytopathology 2004, 94, 44-51. [CrossRef]

13. Prusky, D.; Lichter, A. Activation of quiescent infections by postharvest pathogens during transition from the biotrophic to the necrotrophic stage. FEMS Microbiol. Lett. 2007, 268, 1-8. [CrossRef]

14. Prusky, D.; Alkan, N.; Mengiste, T.; Fluhr, R. Quiescent and necrotrophic lifestyle choice during postharvest disease development. Annu. Rev. Phytopathol. 2013, 51, 155-176. [CrossRef] [PubMed] 
15. Tahir, I.; Nybom, H.; Ahmadi-Afzadi, M.; Røen, K.; Sehic, J.; Røen, D. Susceptibility to blue mold caused by Penicillium expansum in apple cultivars adapted to a cool climate. Eur. J. Hort. Sci. 2015, 80, 117-127. [CrossRef]

16. Grantina-Ievina, L. Fungi causing storage rot of apple fruit in integrated pest management system and their sensitivity to fungicides. Rural Sustain. Res. 2015, 34, 2-11. [CrossRef]

17. Spotts, R.A.; Seifert, K.A.; Wallis, K.M.; Sugar, D.; Xiao, C.L.; Serdani, M.; Henriquez, J.L. Description of Cryptosporiopsis kienholzii and species profiles of Neofabraea in major pome fruit growing districts in the Pacific Northwest USA. Mycol. Res. 2009, 113, 1301-1311. [CrossRef] [PubMed]

18. Sutton, T.B.; Aldwinckle, H.S.; Agnello, A.M.; Walgenbach, J.F. (Eds.) Bitter rot. In Compendium of Apple and Pear Diseases and Pests, 2nd ed.; The American Phytopathological Society: St. Paul, MN, USA, 2014; pp. $20-21$.

19. Tahir, I. What spoils Swedish apples during storage? Acta Hortic. 2019, 1256, 463-468. [CrossRef]

20. Weber, R.W.S.; Dralle, N. Fungi associated with blossom-end rot of apples in Germany. Eur. J. Hortic. Sci. 2013, 78, 97-105.

21. Konstantinou, S.; Karaoglanidis, G.; Bardas, G.; Minas, I.; Doukas, E.; Markoglou, A. Postharvest fruit rots of apple in Greece: Pathogen incidence and relationships between fruit quality parameters, cultivar susceptibility, and patulin production. Plant Dis. 2011, 95, 666-672. [CrossRef]

22. Guan, Y.; Chang, R.; Liu, G.; Wang, Y.; Wu, T.; Han, Z.; Zhang, X. Role of lenticels and microcracks on susceptibility of apple fruit to Botryosphaeria dothidea. Eur. J. Plant Pathol. 2015, 143, 317-330. [CrossRef]

23. Bui, T.T.A.; Wright, S.A.I.; Falk, A.B.; Vanwalleghem, T.; Van Hemmelrijck, W.; Hertog, M.L.A.T.M.; Keulemans, J.; Davey, M.W. Botrytis cinereal differentially induces postharvest antioxidant responses in 'Braeburn' and 'Golden Delicious' apple fruit. J. Sci. Food Agricult. 2019, 99, 5662-5670. [CrossRef] [PubMed]

24. Ma, L.; He, J.; Liu, M.; Zhou, H. The phenylpropanoid pathway affects apple fruit resistance to Botrytis cinerea. J. Phytopathol. 2017, 66, 206-215. [CrossRef]

25. Spotts, R.A.; Cervantes, L.A.; Mielke, E.A. Variability in postharvest decay among apple cultivars. Plant Dis. 1999, 83, 1051-1054. [CrossRef]

26. Suktawee, S.; Shishido, M.; Wang, S.; Saito, T.; Okawa, K.; Ohara, H.; Nimitkeatkai, H.; Ikeura, H.; Kondo, S. n-Propyl dihydrojasmonates influence ethylene signal transduction in infected apple fruit by Botrytis cinerea. Hortic. J. 2019, 88, 41-49. [CrossRef]

27. Biggs, A.R.; Miller, S.S. Relative susceptibility of selected apple cultivars to Colletotrichum acutatum. Plant Dis. 2001, 85, 657-660. [CrossRef] [PubMed]

28. Everett, K.R.; Pushparajah, I.P.S.; Fisher, B.M.; Wood, P.N. A simple method for conidial production and establishing latent infections of apples by Phlyctema vagabunda (syn: Neofabraea alba). N. Z. Plant Protect. 2017, 70, 106-111. [CrossRef]

29. González, E.; Sutton, T.B.; Correll, J.C. Clarification of the etiology of Glomerella leaf spot and bitter rot of apple caused by Colletotrichum spp. based on morphology and genetic, molecular, and pathogenicity tests. Phytopathology 2006, 96, 982-992. [CrossRef]

30. Grammen, A.; Van Campenhout, J.; Geeraerd, A.; Keulemans, W. Susceptibility of apple fruits (Malus $\times$ domestica Borkh.) to the postharvest pathogen Colletotrichum fioriniae: Cultivar differences and correlation with fruit ripening characteristics. Eur. J. Plant Pathol. 2019, 155, 801-816. [CrossRef]

31. Jurick, W.M.; Janisiewicz, W.J.; Saftner, R.A.; Vico, I.; Gaskins, V.L.; Park, E.; Forsline, P.L.; Fazio, G.; Conway, W.S. Identification of wild apple germplasm (Malus spp.) accessions with resistance to the postharvest decay pathogens Penicillium expansum and Colletotrichum acutatum. Plant Breed. 2011, 130, 481-486. [CrossRef]

32. Barad, S.; Sela, N.; Kumar, D.; Kumar-Dubey, A.; Glam-Matana, N.; Sherman, A.; Prusky, D. Fungal and host transcriptome analysis of $\mathrm{pH}$-regulated genes during colonization of apple fruits by Penicillium expansum. BMC Genom. 2016, 17, 330. [CrossRef] [PubMed]

33. Bi, F.; Barad, S.; Ment, D.; Luria, N.; Dubey, A.; Casado, V.; Glam, N.; Diaz Minguez, J.; Espeso, E.A.; Fluhr, R.; et al. Carbon regulation of environmental $\mathrm{pH}$ by secreted small molecules that modulate pathogenicity in phytopathogenic fungi. Mol. Plant Pathol. 2016, 17, 1178-1195. [CrossRef] [PubMed]

34. Liang, X.; Shang, S.; Dong, Q.; Wang, B.; Zhang, R.; Gleason, M.L.; Sun, G. Transcriptomic analysis reveals candidate genes regulating development and host interactions of Colletotrichum fructicola. BMC Genom. 2018, 19, 557. [CrossRef] [PubMed] 
35. Liu, Y.; Lan, J.; Li, Q.; Zhang, Y.; Wang, C.; Dai, H. Rapid location of Glomerella leaf spot resistance gene locus in apple by whole genome re-sequencing. Mol. Breed. 2017, 37, 96. [CrossRef]

36. Liu, Y.; Lan, J.; Wang, C.; Li, B.; Zhu, J.; Liu, C.; Dai, H. Investigation and genetic mapping of a Glomerella leaf spot resistance locus in apple. Plant Breed. 2017, 136, 119-125. [CrossRef]

37. Velho, A.C.; Rockenbach, M.F.; Mondino, P.; Stadnik, M.J. Modulation of oxidative responses by a virulent isolate of Colletotrichum fructicola in apple leaves. Fungal Biol. 2016, 120, 1184-1193. [CrossRef]

38. Schovánková, J.; Opatová, H. Changes in phenols composition and activity of phenylalanine-ammonia lyase in apples after fungal infections. Hortic. Sci. (Prague) 2011, 38, 1-10. [CrossRef]

39. Bogo, A.; Comparin, C.C.; Valdebenito Sanhueza, R.M.; Ritschel, P.; Casa, R.T.; Silva, F.N.; Everhart, S.E. Characterization of Neofabraea actinidiae and N. brasiliensis as causal agents of apple bull's-eye rot in southern Brazil. Can. J. Plant Pathol. 2018, 40, 229-237. [CrossRef]

40. Blažek, J.; Opatová, H.; Goliáš, J.; Homutová, I. Ideotype of apples with resistance to storage diseases. Hort. Sci. (Prague) 2007, 34, 107-113. [CrossRef]

41. Cameldi, I.; Neri, F.; Ventrucci, D.; Ceredi, G.; Muzzi, E.; Mari, M. Influence of harvest date on bull's eye rot of 'Cripps Pink' apple and control chemcial strategies. Plant Dis. 2016, 100, 11. [CrossRef]

42. Cameldi, I.; Neri, F.; Menghini, M.; Pirondi, A.; Nanni, I.; Collina, M.; Mari, M. Characterization of Neofabraea vagabunda isolates causing apple bull's eye rot in Italy (Emilia-Romagna region). Plant Pathol. 2017, 51, 155-176. [CrossRef]

43. Di Francesco, A.; Cameldi, I.; Neri, F.; Barbanti, L.; Folchi, A.; Spadoni, A.; Baraldi, E. Effect of apple cultivars and storage periods on the virulence of Neofabraea spp. Plant Pathol. 2019, 68, 1525-1532. [CrossRef]

44. Gariepy, T.D.; Rahe, J.E.; Lévesque, C.A.; Spotts, R.A.; Sugar, D.L.; Heriquez, J.L. Neofabraea species associated with bull's-eye rot and cankers of apple and pear in the Pacific Northwest. Can. J. Plant Pathol. 2005, 27, 118-124. [CrossRef]

45. Guthrie, E.J. The occurrence of Pezicula alba sp.nov. and P. malicorticis, the perfect state of Gloeosporium album and G. perennans, in England. Trans. Brit. Mycol. Soc. 1959, 42, 502-506. [CrossRef]

46. Aguilar, C.G.; Mazzola, M.; Xiao, C.-L. Timing of apple fruit infection by Neofabraea perennans and Neofabraea kienholzii in relation to bull's-eye rot development in stored apple fruit. Plant Dis. 2017, 101, 800-806. [CrossRef] [PubMed]

47. Tahir, I.; Gustavsson, K. Improving quality and storability of apples by a combination of aluminum reflective mulch, summer pruning and controlled nitrogen fertilization. Acta Hortic. 2010, 877, 245-250. [CrossRef]

48. Tahir, I.; Ahmadi-Afzadi, M.; Nybom, H.; Dey, E.S. Alkylresorcinols isolated from rye bran inhibit growth of Penicillium expansum and Neofabraea perennans in vitro and on fungal-inoculated fruits of four apple cultivars. Eur. J. Hortic. Sci. 2014, 79, 218-225.

49. Tahir, I.; Dey, E.; Nybom, H. Application of alkylresorcinols in an organic apple orchard for protection against storage diseases. Eur. J. Horticult. Sci. 2019, 84, 142-151. [CrossRef]

50. Xu, X.-M.; Robinson, J.D. Effects of fruit maturity and wetness on the infection of apple fruit by Neonectria galligena. Plant Pathol. 2010, 59, 542-547. [CrossRef]

51. Ahmadi-Afzadi, M.; Orsel, M.; Pelletier, S.; Bruneau, M.; Proux-Wéra, E.; Nybom, H.; Renou, J.-P. Genome-wide expression analysis suggests a role for jasmonates in the resistance to blue mold in apple. Plant Growth Regul. 2018, 85, 375-387. [CrossRef]

52. Ballester, A.-R.; Norelli, J.; Burchard, E.; Abdelfattah, A.; Levin, E.; González-Candelas, L.; Droby, S.; Wisniewski, M. Transcriptomic response of resistant (PI613981-Malus sieversii) and susceptible (Royal Gala) genotypes of apple to blue mold (Penicillium expansum) infection. Front. Plant Sci. 2017, 8, 1981. [CrossRef] [PubMed]

53. Chávez, R.A.S.; Peniche, R.T.M.; Medrano, S.A.; Muñoz, L.S.; Ortíz, M.D.S.C.; Espasa, N.T.; Sanchis, R.T. Effect of maturity stage, ripening time, harvest year and fruit characteristics on the susceptibility to Penicillium expansum link. of apple genotypes from Queretaro, Mexico. Scientia Hortic. 2014, 180, 86-93. [CrossRef]

54. Gong, D.; Bi, Y.; Jiang, H.; Xue, S.; Wang, Z.; Li, Y.; Zong, Z.; Prusky, D. A comparison of postharvest physiology, quality and volatile compounds of 'Fuji' and 'Delicious' apples inoculated with Penicillium expansum. Postharvest Biol. Technol. 2019, 150, 95-104. [CrossRef]

55. Hadas, Y.; Goldberg, I.; Pines, O.; Prusky, D. Involvement of gluconic acid and glucose oxidase in the pathogenicity of Penicillium expansum in apples. Phytopathology 2007, 97, 384-390. [CrossRef] [PubMed] 
56. Janisiewicz, W.J.; Saftner, R.A.; Conway, W.S.; Forsline, P.L. Preliminary evaluation of apple germplasm from Kazakhstan for resistance to postharvest blue mold in fruit caused by Penicillium expansum. HortScience 2008, 43, 420-426. [CrossRef]

57. Janisiewicz, W.J.; Nichols, B.; Bauchan, G.; Chao, T.C.; Jurick, W.M. Wound responses of wild apples suggest multiple resistance mechanism against blue mold decay. Postharvest Biol. Technol. 2016, 117, 132-140. [CrossRef]

58. Naeem-Abadi, T.; Keshavarzi, M.; Alaee, H.; Hajnagari, H.; Hoseinava, S. Blue mold (Penicillium expansum) decay resistance in apple cultivars, and its association with fruit physicochemical traits. J. Agric. Sci. Technol. 2014, 16, 635-644.

59. Norelli, J.L.; Wisniewski, M.; Fazio, G.; Burchard, E.; Gutierrez, B.; Levin, E.; Droby, S. Genotyping-by-sequencing markers facilitate the identification of quantitative trait loci controlling resistance to Penicillium expansum in Malus sieversii. PLoS ONE 2017, 12. [CrossRef]

60. Spoor, T.; Rumpunen, K.; Sehic, J.; Ekholm, A.; Tahir, I.; Nybom, H. Chemical contents and blue mould susceptibility in Swedish-grown cider apple cultivars. Eur. J. Hortic. Sci. 2019, 84, 131-141. [CrossRef]

61. Sun, J.; Janisiewicz, W.J.; Nichols, B.; Jurick, W.M.; Chen, P. Composition of phenolic compounds in wild apple with multiple resistance mechanisms against postharvest blue mold decay. Postharvest Biol. Technol. 2017, 127, 68-75. [CrossRef]

62. Tannous, J.; Kumar, D.; Sela, N.; Sionov, E.; Prusky, D.; Keller, N.P. Fungal attack and host defence pathways unveiled in near-avirulent interactions of Penicillium expansum creA mutants on apples. Molec. Plant Pathol. 2018, 19, 2635-2650. [CrossRef] [PubMed]

63. Vilanova, L.; Viñas, I.; Torres, R.; Usall, J.; Buron-Moles, G.; Teixidó, N. Acidification of apple and orange hosts by Penicillium digitatum and Penicillium expansum. Int. J. Food Microbiol. 2014, 178, 39-49. [CrossRef] [PubMed]

64. Vilanova, L.; Vall-Llaura, N.; Torres, R.; Usall, J.; Teixidó, N.; Larrigaudière, C.; Giné-Bordonaba, J. Penicillium expansum (compatible) and Penicillium digitatum (non-host) pathogen infection differentially alter ethylene biosynthesis in apple fruit. Plant Physiol. Biochem. 2017, 120, 132-143. [CrossRef] [PubMed]

65. Wang, K.; Zheng, X.; Zhang, X.; Zhao, L.; Yang, Q.; Boateng, N.A.S.; Ahima, J.; Liu, J.; Zhang, H. Comparative transcriptomic analysis of the interaction between Penicillium expansum and apple fruit (Malus pumila Mill.) during early stages of infection. Microorganisms 2019, 7, 495. [CrossRef]

66. Žebeljan, A.; Vico, I.; Duduk, N.; Žiberna, B.; Urbanek Krajnc, A. Dynamic changes in common metabolites and antioxidants during Penicillium expansum-apple fruit interactions. Physiol. Molec. Plant Pathol. 2019, 106, 166-174. [CrossRef]

67. Everett, K.R.; Pushparajah, I.P.S.; Timudo, O.E.; Chee, A.A.; Scheper, R.W.A.; Shaw, P.W.; Spiers, T.M.; Taylor, J.T.; Wallis, D.R.; Wood, P.N. Infection criteria, inoculum sources and splash dispersal pattern of Colletotrichum acutatum causing bitter rot of apple in New Zealand. Eur. J. Plant Pathol. 2018, 152, 367-383. [CrossRef]

68. Coton, M.; Bregier, T.; Poirier, E.; Debaets, S.; Arnich, N.; Coton, E.; Dantigny, P. Production and migration of patulin in Penicillium expansum molded apples during cold and ambient storage. Int. J. Food Microbiol. 2020, 313, 108377. [CrossRef]

69. Zhong, L.; Carere, J.; Lu, Z.; Lu, F.; Zhou, T. Patulin in apples and apple-based food products: The burdens and the mitigation strategies. Toxins 2018, 10, 475. [CrossRef]

70. Jönsson, Å.; Tahir, I. Evaluation of scab resistant apple cultivars in Sweden. J. Fruit Ornament. Plant Res. 2004, 12, 223-232. [CrossRef]

71. Tahir, I.I.; Johansson, E.; Olsson, M.E. Improvement of quality and storability of apple cv. Aroma by adjustment of some pre-harvest conditions. Sci. Hortic. 2007, 112, 164-171. [CrossRef]

72. Børve, J.; Røen, D.; Stensvand, A. Harvest time influences incidence of storage diseases and fruit quality in organically grown 'Aroma' apples. Eur. J. Hortic. Sci. 2013, 78, 232-238.

73. Torres, R.; Valentines, M.C.; Usall, J.; Vinas, I.; Larrigaudiere, C. Possible involvement of hydrogen peroxide in the development of resistance mechanisms in 'Golden Delicious' apple fruit. Postharvest Biol. Technol. 2003, 27, 235-242. [CrossRef]

74. Valiuškaitè, A.; Kviklienė, N.; Kviklys, D.; Lanauskas, J. Post-harvest fruit rot incidence depending on apple maturity. Agron. Res. 2006, 4, 427-431. 
75. Kondo, S.; Meemak, S.; Ban, Y.; Moriguchi, T.; Harada, T. Effects of auxin and jasmonates on 1-aminocyclopropane-1-carboxylate (ACC) synthase and ACC oxidase gene expression during ripening on apple fruit. Postharvest Biol. Technol. 2009, 51, 281-284. [CrossRef]

76. Lv, J.; Zhang, M.; Zhang, J.; Ge, Y.; Li, C.; Meng, K.; Li, J. Effects of methyl jasmonate on expression of genes involved in ethylene biosynthesis and signaling pathway during postharvest ripening of apple fruit. Sci. Hortic. 2018, 229, 157-166. [CrossRef]

77. Costa, F.; Stella, S.; Van de Weg, W.E.; Guerra, W.; Cecchinel, M.; Dalla Via, J.; Koller, B.; Sansavini, S. Role of the genes Md-ACO1 and Md-ACS1 in ethylene production and shelf life of apple (Malus domestica Borkh). Euphytica 2005, 141, 181-190. [CrossRef]

78. Nybom, H.; Ahmadi-Afzadi, M.; Sehic, J.; Hertog, M. DNA marker-assisted evaluation of fruit firmness at harvest and post-harvest fruit softening in a diverse apple germplasm. Tree Genet. Genomes 2013, 9, 279-290. [CrossRef]

79. Levin, E.; Kishore, A.; Ballester, A.R.; Raphael, G.; Feigenberg, O.; Liu, Y.; Norelli, J.; Gonzalez-Candelas, L.; Wisniewski, M.; Droby, S. Identification of pathogenicity-related genes and the role of a subtilisin-related peptidase S8 (PePRT) in authophagy and virulence of Penicillium expansum on apples. Postharvest Biol. Technol. 2019, 149, 209-220. [CrossRef]

80. Sun, R.; Chang, Y.; Yang, F.; Wang, Y.; Li, H.; Zhao, Y.; Chen, D.; Wu, T.; Zhang, X.; Han, Z. A dense SNP genetic map constructed using restriction site-associated DNA sequencing enables detection of QTLs controlling apple fruit quality. BMC Genom. 2015, 16, 747. [CrossRef]

81. Farneti, B.; Di Guardo, M.; Khomenko, I.; Capellin, L.; Biasioli, F.; Velasco, R.; Costa, F. Genome-wide association study unravels the genetic control of the apple volatilome and its interplay with fruit texture. J. Exp. Bot. 2017, 68, 1467-1478. [CrossRef]

82. Di Guardo, M.; Bink, M.C.A.M.; Guerra, W.; Letschka, T.; Lozano, L.; Busatto, N.; Poles, L.; Tadiello, A.; Bianco, L.; Visser, R.G.F.; et al. Deciphering the genetic control of fruit texture in apple by multiple family-based analysis and genome-wide association. J. Exp. Bot. 2017, 68, 1451-1466. [CrossRef] [PubMed]

83. Bianco, L.; Cestaro, A.; Linsmith, G.; Muranty, H.; Denancé, C.; Théron, A.; Poncet, C.; Micheletti, D.; Kerschbamer, E.; Di Pierro, E.A.; et al. Development and validation of the Axiom ${ }^{\circledR}$ Apple 480 K SNP genotyping array. Plant J. 2016, 86, 62-74. [CrossRef] [PubMed]

84. Urrestarazu, J.; Muranty, H.; Denancé, C.; Leforestier, D.; Ravon, E.; Guyader, A.; Guisnel, R.; Feugey, L.; Aubourg, S.; Celton, J.-M.; et al. Genome-wide association mapping of flowering and ripening periods in apple. Front. Plant Sci. 2017, 8, 1923. [CrossRef] [PubMed]

85. Visscher, P.M.; Hemani, G.; Vinkhuyzen, A.A.E.; Chen, G.-B.; Lee, S.H.; Wray, N.R.; Goddard, M.E.; Yang, J. Statistical power to detect genetic (co)variance of complex traits using SNP data in unrelated samples. PLoS Genet. 2014, 10, e1004269. [CrossRef] [PubMed]

86. Brookfield, P.; Murphy, P.; Harker, R.; MacRae, E. Starch degradation and starch pattern indices; interpretation and relationship to maturity. Postharvest Biol. Technol. 1997, 11, 23-30. [CrossRef]

87. Zhu, Y.; Zheng, P.; Varanasi, V.; Shin, S.; Main, D.; Curry, E.; Mathesis, J. Multiple plant hormones and cell wall metabolism regulate apple fruit maturation patterns and texture attributes. Tree Genet. Genomes 2012, 8 , 1389-1406. [CrossRef]

88. Costa, F.; Cappellin, L.; Longhi, S.; Guerra, W.; Magnago, P.; Porro, D.; Soukoulis, C.; Salvi, S.; Velasco, R.; Biasioli, F.; et al. Assessment of apple (Malus $\times$ domestica Borkh.) fruit texture by a combined acoustic-mechanical profiling strategy. Postharvest Biol. Technol. 2011, 61, 21-28. [CrossRef]

89. Alexander, T.R.; King, J.; Zimmerman, A.; Miles, C.A. Regional variation in juice quality characteristics of four cider apple (Malus $\times$ domestica Borkh.) cultivars in Northwest and Central Washington. HortScience 2016, 51, 1489-1502. [CrossRef]

90. Da, R.N.A.; Luiz, C.; Maraschin, M.; Di, P.R. Efficacy of salicylic acid to reduce Penicillium expansum inoculum and preserve apple fruits. Int. J. Food Microbiol. 2016, 221, 54-60.

91. Chagné, D.; Dayatilake, D.; Diack, R.; Oliver, M.; Ireland, H.; Watson, A.; Gardiner, S.E.; Johnston, J.W.; Schaffer, R.J.; Tustin, S. Genetic and environmental control of fruit maturation, dry matter and firmness in apple (Malus $\times$ domestica Borkh.). Hortic. Res. 2014, 1, 14046. [CrossRef]

92. Kenis, K.; Keulemans, J.; Davey, M.K. Identifiction and stability of QTLs for fruit quality traits in apple. Tree Genet. Genomes 2008, 4, 647-661. [CrossRef] 
93. Kunihisa, M.; Moriya, S.; Abe, K.; Okada, K.; Haji, T.; Hayashi, T.; Kim, H.; Nishitani, C.; Terakami, S.; Yamamoto, T. Identification of QTLs for fruit quality traits in Japanese apples: QTLs for early ripening are tightly related to preharvest fruit drop. Breed. Sci. 2014, 64, 240-251. [CrossRef]

94. Kunihisa, M.; Moriya, S.; Abe, K.; Okada, K.; Haji, T.; Hayashi, T.; Kawahara, Y.; Itoh, R.; Itoh, T.; Katayose, Y.; et al. Genomic dissection of a 'Fuji' apple cultivar: Re-sequencing, SNP marker development, definition of haplotypes, and QTL detection. Breed Sci. 2016, 66, 499-515. [CrossRef]

95. Liebhard, R.; Kellerhals, M.; Pfammatter, W.; Jertmini, M.; Gessler, C. Mapping quantitative physiological traits in apple (Malus $\times$ domestica Borkh.). Plant Mol. Biol. 2003, 52, 511-526. [CrossRef] [PubMed]

96. Morimoto, T.; Hiramatsu, Y.; Banno, K. A major QTL controlling earliness of fruit maturity linked to the red leaf/red flesh trait in apple cv. 'Maypole'. J. Jpn. Soc. Hortic. Sci. 2013, 82, 97-105. [CrossRef]

97. Migicovsky, Z.; Gardner, K.M.; Money, D.; Sawler, J.; Bloom, J.S.; Moffett, P.; Chao, C.T.; Schwaninger, H.; Fazio, G.; Zhong, G.-Y.; et al. Genome to phenome mapping in apple using historical data. Plant Genome 2016, 9. [CrossRef] [PubMed]

98. Chagné, D.; Vanderzande, S.; Kirk, C.; Profitt, N.; Weskett, R.; Gardiner, S.E.; Peace, C.P.; Volz, R.K.; Bassil, N.V. Validation of SNP markers for fruit quality and disease resistance loci in apple (Malus $\times$ domestica Borkh.) using the OpenArray ${ }^{\circledR}$ platform. Hortic. Res. 2019, 6, 30. [CrossRef] [PubMed]

99. Costa, F.; Peace, C.P.; Stella, S.; Serra, S.; Musacchi, S.; Bazzani, M.; Sansavini, S.; Van de Weg, W.E. QTL dynamics for fruit firmness and softening around an ethylene-dependent polygalacturonase gene in apple (Malus $\times$ domestica Borkh.). J. Exp. Bot. 2010, 61, 3029-3039. [CrossRef]

100. Longhi, S.; Moretto, M.; Viola, R.; Velasco, R.; Costa, F. Comprehensive QTL mapping survey dissects the complex fruit texture physiology in apple (Malus $\times$ domestica Borkh.). J. Exp. Bot. 2012, 63, 1107-1121. [CrossRef]

101. Bai, Y.; Dougherty, L.; Li, M.; Faxio, G.; Cheng, L.; Xu, K. A natural mutation-led truncation in one of the two aluminum-activated malate transporter-like genes at the Ma locus is associated with low fruit acidity in apple. Mol. Genet. Genom. 2012, 287, 663-678. [CrossRef]

102. Ahmadi-Afzadi, M.; Nybom, H.; Kirk, C.; Chagné, D. Association between blue mold resistance and qPCR-based molecular markers in apple. Acta Horticult. in press.

(C) 2020 by the authors. Licensee MDPI, Basel, Switzerland. This article is an open access article distributed under the terms and conditions of the Creative Commons Attribution (CC BY) license (http://creativecommons.org/licenses/by/4.0/). 